Finding Voice in a Changing Ecological and Political Landscape - Traditional Knowledge and Resource Management in Settled and Unsettled Claim Areas of the Northwest Territories, Canada

Brenda Parlee

Assistant Professor, Faculty of Native Studies /

Assistant Professor, Faculty of Agricultural Life and Environmental Sciences

University of Alberta

aboriginal policy studies Vol. 2, no. 1, 2012, pp. 56-87

This article can be found at:

http://ejournals.library.ualberta.ca/index.php/aps/article/view/17704

ISSN: $1923-3299$

Article DOI: http://dx.doi.org/10.5663/aps.v2i1.17704

aboriginal policy studies is an online, peer-reviewed and multidisciplinary journal that publishes original, scholarly, and policy-relevant research on issues relevant to Métis, non-status Indians and urban Aboriginal people in Canada. For more information, please contact us at apsjournal@ualberta.ca or visit our website at www.ualberta.ca/nativestudies/aps/. 


\title{
Finding Voice in a Changing Ecological and Political Landscape - Traditional Knowledge and Resource Management in Settled and Unsettled Claim Areas of the Northwest Territories, Canada
}

\author{
Brenda Parlee \\ Assistant Professor, Faculty of Native Studies / \\ Assistant Professor, Faculty of Agricultural Life and Environmental Sciences \\ University of Alberta
}

\begin{abstract}
The Traditional Knowledge Policy (1994) of the Government of the Northwest Territories (GNWT) provides the First Nations, Inuit, and Métis peoples of the NWT with a useful basis for influencing the management of land, water, wildlife, and other valued resources. The mechanisms of such influence are not always clear, however, particularly for those unfamiliar with the details of the bureaucratic process. This paper developed around the question, "what ecological and social (institutional) factors affect how, when, and to what extent Traditional Knowledge holders have voice in decisions about key resource management issues?" More specifically, does the ecological scale of the resource management problem and the settlement of Comprehensive Land Claim Agreements matter? Using forest fire management, non-renewable resource development, and climate change as case studies, the paper identifies a diversity of institutional arrangements in settled and unsettled land claim areas of the NWT by which Traditional Knowledge can have significant influence over resource management decision-making.
\end{abstract}

\section{Introduction}

The Government of the Northwest Territories recognizes that the Aboriginal peoples of the Northwest Territories have acquired a vast store of traditional knowledge through their experience of centuries of living in close harmony with the land. The Government recognizes that aboriginal traditional knowledge is a valid and essential source of information about the natural environment and its resources, the use of natural resources, and the relationship of people to the land and to each other, and will incorporate traditional knowledge into government decisions and actions where appropriate (GNWT 2005).

In many parts of the North, there are growing opportunities to include Traditional Knowledge in the planning, management, and monitoring of lands and resources valued by Aboriginal peoples. Many are the result of legal obligations incurred by land claim settlements or case law on consultation; others are coming from softer sets of arrangements that seem to stem from interest in Traditional Knowledge as a means of advancing the social and ecological value of resource management systems. Taken together, these opportunities are part of a system of governance that addresses many kinds of resource management problems on many different ecological scales.

aboriginal policy studies, Vol. 2, no. 1, 2012 
These obligations to consider Traditional Knowledge in the Northwest Territories are setting precedent for other parts of Canada, and for Indigenous knowledge holders globally. With the exception of Nunavut and the requirements set out in the Nunavut Final Agreement (Government of Canada 1993), the Northwest Territories has more mechanisms for the inclusion of Traditional Knowledge as the Northwest Territories than any other jurisdiction, owing in large part to the settlement of land claims in the Inuvialuit, Gwich'in, Sahtú, and Tlị Chọ regions, and the associated devolution of authority to comanagement authorities (Stevenson 2006). "Political and social shifts towards greater autonomy through comprehensive land claims and devolution have opened the door to localized approaches to resource management" (Christensen and Grant 2006, 11). Despite these opportunities, Traditional Knowledge has been perceived to have had a very limited influence over actual decision-making, and particularly over decisions related to large scale resource development projects (Ellis 2005; Howitt 2001). Scholars have attributed this to the dominance of Western scientific or Euro-Canadian thinking in this and other jurisdictions (Nadasdy 2003; Howitt 2001). There are also many historical, political, social, and cultural barriers that make interaction and communication difficult. Even co-management boards deemed to be successful at incorporating Traditional Knowledge, such as the Beverley Qaminiurjuaq Caribou Management Board, are challenged by an absence of trust between Traditional Knowledge holders and scientists (Kendrick 2003). This lack of trust is not unique to Aboriginal peoples; critics of Traditional Knowledge worry that the spiritual and cultural values that underlie this knowledge system will decrease the rigour and credibility of processes like environmental assessment (Howard and Widdowson 1996).

Despite the criticisms of some scholars and pseudo policy analysts, Traditional Knowledge is unlikely to disappear from the resource management stage in the Canadian North; even the efforts of federal governments to eviscerate institutions of Aboriginal governance are unlikely to do long-term harm (McCrank 2008). Requirements for the inclusion of Traditional Knowledge are deeply embedded both in policy and legislation, and are tied to a large body of case law on Aboriginal rights and consultation.

In 1994, the Government of the Northwest Territories (GNWT) developed a Traditional Knowledge Policy that challenged NWT policy makers to "incorporate Traditional Knowledge into government decisions where appropriate” (GNWT 2005, 1). Four years later, the federal government passed the Mackenzie Valley Resource Management Act (Government of Canada 1998), which instructed newly created co-management boards to consider any Traditional Knowledge while conducting environmental assessments, and in the management and monitoring of the cumulative effects of development. Both the Policy and the Act have set precedent in Canada by providing legal leverage to Aboriginal peoples in the Territory that allows them to influence resource management decision-making. However, within the administrative jurisdiction of the Mackenzie Valley, and the Northwest Territories more broadly, there are significant differences in the legal clout attributed to Aboriginal governments and in their capacities to ensure their knowledge is meaningfully considered. Those with settled land claim areas within the Mackenzie Valley, including the Gwich'in, Sahtú, and Tlị Chọ governments, may have greater advantage than those in 
the Deh Cho and Akaitcho regions (Figure 1) because of the legal terms of the agreements and the capacities of their associated Land Use Planning Boards, Land and Water Boards, Renewable Resources Boards and Councils, and representation on the Mackenzie Valley Environmental Impact Review Board.

FIGURE 1: Unsettled and Settled Land Claims in the NWT

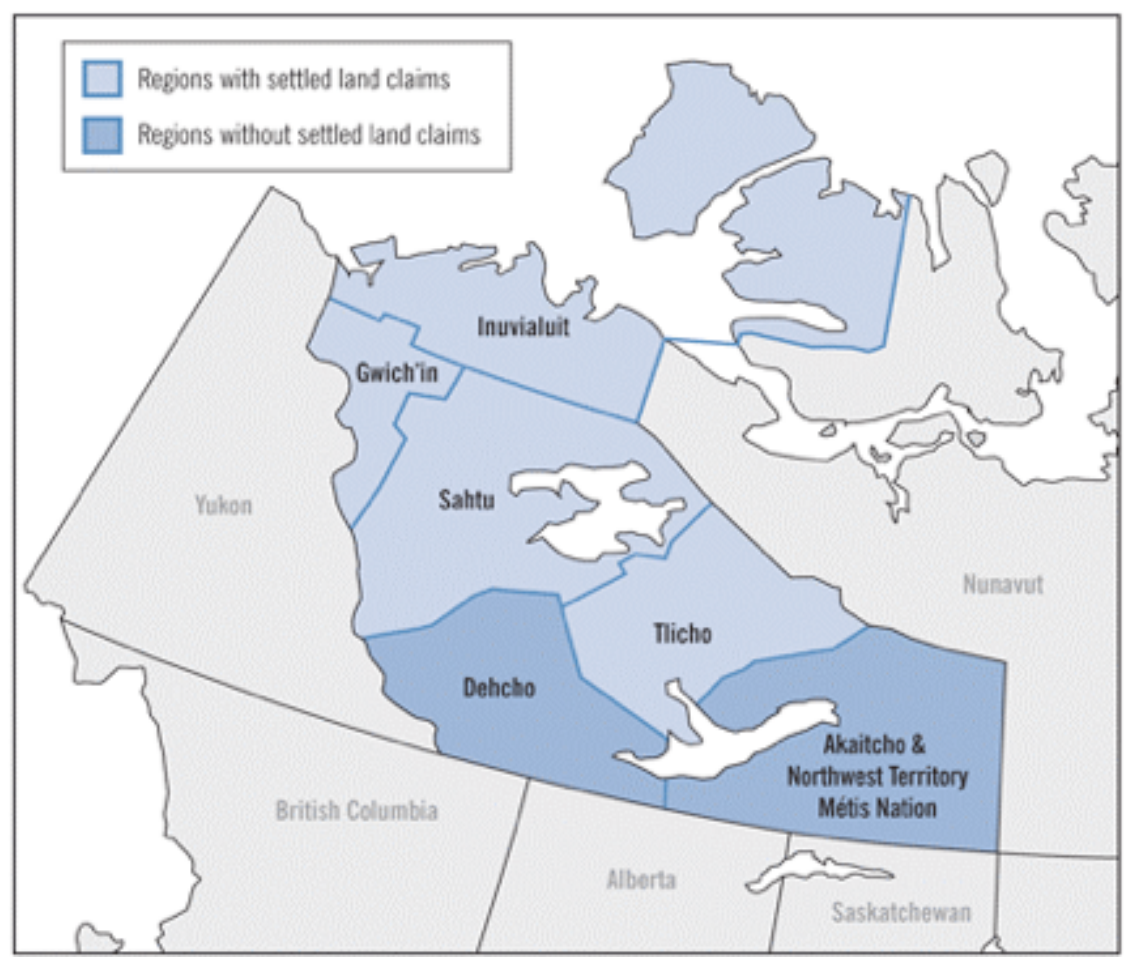

Source: Office of the Auditor General of Canada. http://tinyurl.com/7df4kle

A review of the many institutional arrangements in place in the Mackenzie Valley suggests that the patterns of opportunity for including Traditional Knowledge in resource management also vary on an ecological scale. Venues where Aboriginal people find voice in global protocols on climate change, for example, are different than forums that exist at regional and local scales on issues such as the impact of mining and forest fire management. Questions of ecological scale have not been well discussed in the literature to date.

An overarching challenge in both settled and unsettled claim areas is the lack of rigour used in methods in which the "[incorporation of] traditional knowledge into government decisions and actions where appropriate" is made (GNWT 2005). Many boards, agencies, industry public relations advertisements, plans, and strategies for natural resource management claim on a regular basis that they have incorporated Traditional Knowledge into their methods and actions: however, clarity and transparency on matters like when, how, who, and what is often absent. By writing this article, I am attempting to find some clarity and transparency by exploring the mechanisms by which Traditional Knowledge is considered in dealing with three resource management problems of different ecological scales-dealing with forest fires, development of resources, and climate change. 
I also explore how these mechanisms differ between a settled land claim area (Gwich'in Settlement Area) and in a region where the rights and interests of First Nations and Metis have yet to be recognized by the Federal government (Traditional Territory of Łutsël K'e Dene First Nation).

\section{Theoretical Context}

Traditional Knowledge is defined as a cumulative body of knowledge and beliefs that has evolved through adaptive processes and been handed down through generations by cultural transmission (Berkes 2008, 9). For many Aboriginal peoples, Traditional Knowledge holds the values and cultural teachings that guide them in their day-to-day lives. However, its meaning and use can be irrevocably changed as it becomes "used," "integrated," or "considered" by outsiders. More often than not, Traditional Knowledge is viewed in some contexts as a historical dataset with little relevance to contemporary issues of resource management (Ellis 2005). While historical knowledge is a key component of Traditional Knowledge, it has many more components that are not often considered (see Text Box 1). Even where a broader approach is taken, a pervasive concern remains about the bureaucratization, scientization, and commodification of Aboriginal knowledge by resource management institutions (Agrawal 2002; Battiste and Henderson 2000; Nadasdy 2003; Cruikshank 2004; Ellis 2005; White 2006). At the same time, the oversimplification, or homogenization, of northern cultures and ways of knowing is problematic, as are overly reductionist and mechanistic tendencies to dissect and itemize knowledge systems. Community participation in recent Joint Review Panel hearings on the Mackenzie Gas Project, for example, was thought to be limited in large part by the litigious nature of the process and confusion over how, when, and where their voices were to be heard (P. Usher, pers. comm.).

Text Box 1: Categories for Traditional Knowledge for Assessment, Monitoring and Management

Category 1: Factual/rational knowledge about the environment. This includes statements of fact about such matters as weather, ice, coastal waters, currents, animal behaviour, traveling conditions and the like, which are typically based on (a) empirical observations by individuals of specific events or phenomena; (b) generalized observations based on numerous experiences over a long time; or (c) generalized observations based on personal experience reinforced by the accounts of others both living (shared experience, stories, and instruction) and dead (oral history and customary teachings).

Category 2: Factual knowledge about past and current use of the environment (e.g., patterns of land use and occupancy, or harvest levels), or other statements about social or historical matters that bear on the traditional use of the environment and hence the rights and interests of the local aboriginal population in the regional environment.

Category 3: Culturally based value statements about how things should be, and what is fitting and proper to do, including moral or ethical statements about how to behave with respect to animals and the environment, and about human health and well-being in a holistic sense.

Category 4: Underlying the first three categories is a culturally based cosmology-the foundation of the knowledge system-by which information derived from observation, experience, and instruction is organized to provide explanations and guidance. It is the framework with which people construct knowledge from facts (Usher 2000, 186). 
Equal in importance to the consideration of the heterogeneity of northern communities and their knowledge systems is the recognition of the complexity of ecological scenarios in which such knowledge is relevant. In that vein, ecological scale has become an emerging area of academic interest and research with respect to Traditional Knowledge, particularly in northern regions (Gagnon and Berteaux 2009; Berkes 2002; Duerden and Kuhn 1998). The scales at which Aboriginal people relate to and communicate about their natural world are thought to be different to those of science-based discourse, and problems emerge when Traditional Knowledge is transmuted from the scale at which it was generated to other scales of application (Duerden and Kuhn 1998, 33). However, studies on the scales at which Traditional Knowledge and western science are synergistic and the importance of "fit" between knowledge, institutions, and the ecological scenarios under address are now emerging (Gagnon and Berteaux 2009; Folke et al. 2007; Berkes et al. 2003). In essence, one size does not fit all, and careful attention to the complexity surrounding social-ecological relations is necessary for sustainability.

Next in this article is an overview of the methods used to address these questions, an introduction to the people and regions of the Gwich'in Settlement Area and Lutsël K'e Dene First Nation, and a discussion of the issues of forest fire, resource development, and climate change. This discussion is followed by one about the institutional arrangements associated with these three resource management issues and what mechanisms exist within these arrangements for incorporating Traditional Knowledge. The analysis and discussion in this paper reflects upon the knowledge-policy relationship, with the aim of highlighting where and how Aboriginal peoples may have a greater or lesser voice in decision-making within this changing ecological and political landscape.

\section{Methods and Study Area}

This article is based on a review of secondary source material and on interviews with local harvesters and resource people from community organizations, co-management boards, government departments, and other institutions in the Gwich'in and Denesơine regions. The research in this paper is also a reflection of my own direct observations and experience with these institutions as an employee of the Łutsël K'e Dene First Nation Wildlife, Lands, and Environment Committee (1998-2001) and of my research in the Gwich'in Settlement Area (2002-2004). The article also contains excerpts from transcripts that come from my work with the communities Łutsël K'e and Fort McPherson, NWT.

The ecological knowledge of northern communities is considered useful in sorting out and addressing key issues of Arctic sustainability; as climate change and resource development place greater stress on northern ecosystems and communities, there has never been a more important time to look to the knowledge of northern Aboriginal peoples for insight and direction (Nuttall et al. 2004). The North is also undergoing significant institutional change as well as growing ecological change. The settlement of land claims in the Gwich'in, Sahtú, and Tli Chọ regions of the Mackenzie Valley has led to the devolution of federal and territorial government authority over northern lands and resources, while Supreme Court rulings such as Delgamukw v. British Columbia [1997], Haida Nation v. British Columbia (Minister of Forests) [2004], and Taku River Tlingit First Nation v. British 
Columbia [2004] have also created a range of obligations and requirements for consultation and the involvement of Aboriginal people in resource management decision-making. Governments that once operated using a top-down and centralized framework are now involved in more inclusive decision-making processes. New institutions, including comanagement boards and multi-stakeholder agencies, have been created across the North.

The focus of this paper is on the Gwich'in and Denesoline regions of the Northwest Territories. The Gwich'in Settlement Area is a 57,000 square-kilometre region of the Northwest Territories defined by the Gwich'in Comprehensive Land Claim Agreement (1993). A review of the agreement (GCLCA) provides insight into the rights of the Gwich'in to the land and resources of the region, and a study of the institutional arrangements that resulted from the agreement provides additional perspective on how these lands and resources are being managed. Prior to the 1993 land claim agreement, authority for the management of natural resources, such as fish, forests, and wildlife, fell under the jurisdiction of the Federal and Territorial governments. Today, the management of these valued resources is shared with the Gwich'in through a variety of co-management arrangements. The Gwich'in Renewable Resources Board, the Gwich'in Land and Water Board, and the Gwich'in Land Use Planning Board, for example, wield significant authority over resource management decision-making.

The Gwich'in Comprehensive Land Claim Agreement and the settlement of the Sahtu Dene and Metis Comprehensive Land Claim Agreement (1993) also resulted in the development of the Mackenzie Valley Resource Management Act (Government of Canada 1998). This Act was created to facilitate more integrated planning and management up and down the Mackenzie Valley, and led to the creation of a variety of other resource management institutions, including the Mackenzie Valley Land and Water Board and the Mackenzie Valley Environmental Impact Review Board. The federal government (represented by the Department of Aboriginal Affairs and Northern Development) and the Territorial Department of Environment and Natural Resources (GNWT ENR) continue to play major roles in the Gwich'in region.

Unlike the Gwich'in, the rights and interests of the Denesọine of Łutsël K'e Dene First Nation have not, to date, been recognized by the federal government, as it considers the lands of the Denesọine of Łutsël K'e also to fall under the jurisdiction of the Mackenzie Valley Resource Management Act. While the Act and its associated institutions are legislated, the Denesołine and other members of Treaty 8 have been disputing the legitimacy of the Act since its inception in 1998. They argue that the Act disregards their Treaty and inherent rights, and prejudices their own, still ongoing, land claim negotiations. While the communities of Treaty 8 have been able to establish some interim protection of their lands and resources through the Akaticho Interim Measures Agreement (2001), community members continue to be frustrated about their limited role in resource planning and management in the region. 


\section{Ecological Scales of Opportunities-Linking Traditional Knowledge to Forest Fires, Non-Renewable Resource Development, and Climate Change}

\section{Managing Forest Fires}

The Denesọine and Gwich'in have lived a land-based way of life for many generations. Although they have undergone significant social and cultural change over the last half century, resources such as caribou and berries are still an important part of their livelihood. In recent years, however, increases in forest fire activity, non-renewable resource development, and global warming have begun to have an impact on these resources in ways that affect the social, cultural, and physical well-being of their communities.

Historically, the Gwich'in and Denesoline viewed fire as an important part of the ecological cycle; fire cleaned the land and provided new life for all the animals and the people. However, the Denesọline and Gwich'in have expressed concern that forest fires are getting worse, and have experienced a greater number of large fires in areas around their community in recent years. As Elder Pierre Marlowe from Łutsël K’e describes below, this kind of frequent forest fire activity was not common in the past, and the loss of caribou habitat is a growing concern:

Regarding the forest fires ... some scientists say it's good for new growth. But do you know what the caribou eat? If the lichen burns ... it will take over one hundred years for the plants to grow back. Some scientists say the forest fires are good but it's not like that for us. There never used to be so many forest fires. I have never before seen a forest fire started by lightening. We look after the land and we respect the land and the animals (P. Marlowe, interview).

In the Gwich'in region, there are various concerns about the increase in the number of forest fires, but the loss of valued berry patches in particular is a key issue for many women. Unlike on the southern edge of the boreal forest, where fire can be a useful tool in the regeneration of some berry species, the unique sub-arctic ecological conditions in the Gwich'in region significantly limit regeneration (Janzen 1989; Landhäusser et al. 1993). Elders say that "once there has been a fire, we no longer go back there." (P. Marlowe, interview).

Scientific research suggests these kinds of forest fire are likely to increase (Janzen 1989; Landhäusser et al. 1993). Some fire ecologists argue that fifty or more years of fire suppression in the North has fundamentally changed fire ecology in the region and created a homogenized forest landscape vulnerable to fire (A. Applejohn, pers. comm.; Bergeron et al. 1998). Others argue that climate change is responsible for the increasing scale, frequency, and intensity of forest fires (Weber et al. 1997; Lynch et al. 1995; Flannigan et al. 1998; Hassol 2004). It is in this context that the Gwich'in and Denesọtine are seeking to share their observations and knowledge about fire and its effects with resource management decision-makers in the region.

Increased forest fire activity is not the only ecological change being experienced by northern communities. In the Denesọine region, a major issue has been the ecological effects of mining exploration and development. Currently, there are three diamond mines 
in operation in the Bathurst range, and fifty-three land use permits for further mineral exploration or development have been issued in the same region. This number is anticipated to increase further in coming years. Łutsël K'e elders are particularly concerned about the effects of this activity on caribou and subsistence caribou harvesting. Roads, for example, are one major problem as elders perceive the mining roads as barriers to caribou movement, and believe they are affecting local movement as well as seasonal migration. There are additional concerns about the cumulative effects of mineral exploration, in addition to the impact of the roads themselves

In the Gwich'in region, oil and gas exploration and development are the major concern for many people, including elders. This activity, which has been ongoing since the early 1950s, has further increased in recent years as a result of renewed interest in northern gas reserves and a Mackenzie Valley gas pipeline. Point source contamination from fuel spills and other similar activities associated with the oil and gas industry are a key issue for those who live there, as do contaminants associated with the recent failures of permafrost dumps or sumps that were created in the 1960s and 1970s (Kokelj and GeoNorth 2003; NRTEE 2001). As one example, in the Fort McPherson area, an old sump at Caribou River is thought to have leaked a variety of PCBs, metals, and other carcinogenic material into the Peel River and the surrounding area. Seismic lines have also been a major issue. While technology has changed in recent years, the clearing of vegetation that took place thirty to forty years ago has created permanent scars on the landscape, distinct from those that would be caused from natural forest fires or other clearing activities (Seccombe-Hett and Walker-Larsen 2004). While some of these linear features are being used for subsistence harvesting activities, others think these areas may be contaminated, as Fort McPherson resident Christine Firth describes here:

Seismic lines and developments like roads and fires [are a concern]. Back in the 1940s, 50 s, and 60s, when people from down south brought technologies to the north, they did a really sloppy job. Now today we see the damages [that] development has left behind within the Gwich'in lands. Now today we have better ways of protecting the land and working together for a clean and healthy environment (C. Firth, interview).

Of particular concern to the Teetł'it Gwich'in is the area around Caribou River where an old drilling site was found to be leaking (J. Andre, interview). ${ }^{1}$ It is for these reasons that the Denesołine and Gwich'in are worried about increasing non-renewable resource development activity in their regions, and seek to share their knowledge with decisionmakers.

Climate change is also a growing concern for many northern communities, including the Denesọine and Gwich'in communities of Łutsël K'e and Fort McPherson. Research has revealed that climate change is affecting northern communities three times faster than anywhere else in Canada (Hassol 2004). The Denesọine, Gwich'in, and other northern peoples are already observing and experiencing many changes that scientists attribute to global warming; as one northern elder said, "the earth is moving faster now" (Krupnik and Jolly 1998; Berkes and Jolly 2001; Reidlinger and Berkes 2001). 
Gwich'in berry harvesters are also observing greater variability in temperature and precipitation that, in turn, affects the abundance and distribution of berries. While some years, such as 2003, have been extremely good for picking berries, extreme weather events such as a late frost and extremely hot dry weather have all but ruined the seasonal harvest in other years.

I hardly got any cranberries this past fall [2002]; nobody did in this area anyway. Out this way, I checked [toward Tsiigehtchic] and there was hardly anywhere it used to be. I think it was the weather conditions. First, it was too hot ... in June. Then in July, it snowed! And I think that was the cause of no berries ... extreme weather change ... I notice a lot of these changes ... extreme weather condition changes. Like this last summer ... it was extremely hot. It wasn't good for the health of the people. Lots of elders couldn't stand it. It was pretty dangerous. It switched from one extreme of heat to cold rain ... then for about five days it snowed. I was at 8 Miles and it was very very cold. And that is crazy weather! (M. Andre, interview).

Many of the changes experienced by the Denesoline are also weather related. Although average temperature increases in summer and winter are of some concern, unexpected weather events cause many problems, particularly for harvesters who depend on Traditional Knowledge about weather conditions and seasonal observations to guide them while hunting and trapping.

The climate is changing. The wind blows harder than it did in the past. It's different ... the wind picks up quickly and changes quickly; now I don't know what has happened .... In the afternoon you can't even go out onto the lake (N. Drybones, interview).

Changes in wildlife distribution are also apparent. "Little yellow birds" 2 and other songbirds that have never been seen in the region before are suddenly appearing near the community each summer. Other animals that were rarely seen, such as moose, are now appearing in growing numbers around Great Slave Lake and the Thelon River. Other signs of climate change concerning elders are the decreases in water levels. According to many elders and harvesters, the creeks and streams are drying up and the lake levels are decreasing. Although there has always been some variability in water levels, these recent changes are confusing to many elders-"somehow we seem to be losing water" (M. Lockhart, interview). These changes in water levels also present problems for resource harvesters. The portage used by the community to cross Peithii Peninsula on Great Slave Lake, for example, has increased many feet in the last ten years, making it almost unusable to harvesters who have to physically push their fishing boats along the trail. Other rivers, such as the Snowdrift River, are drying up, as described here by Elder Noel Drybones:

At one place in Whitefish Lake I got stuck on an island because of this. Toward the Thelon River ... things have changed also. A long time ago, my sister and me traveled on the Snowdrift River to Siltaza Lake. We never saw any rocks along that river but today you can see lots of rocks [the river is shallow]. (N. Drybones, interview, May 11, 2000)

For many elders, these changes are surprising-outside their memory of natural variability; unlike other natural changes in the environment-and describe them in terms of edọ ajá: "something has happened to it" (Parlee et al. 2004). It is for these reasons that the Gwich'in and Denesọine wish to share their local and Traditional Knowledge with those institutions involved in dealing with the climate change issue. Edọ ajá-something, and something profound, is happening! 
While the effects of forest fire, non-renewable resource development, and climate change are felt acutely at the local level, there are many institutions at the regional, territorial, national, and international level that are involved in the management of these resource management problems. Each of these institutions offer different kinds of opportunities for incorporating Traditional Knowledge.

Opportunities for including Traditional Knowledge in forest fire management decisionmaking have changed significantly over the last two decades. Beginning in the 1930s, and to a greater extent in the period after World War II, the federal government was actively involved in forest fire management. The federal approach to fire protection, tied in with federal interests in exercising authority over the region and its resources, was among the "best examples [of colonialism] whereby Ottawa officials directed matters of local concern" (Janzen 1989, 114). This centralized, top-down approach significantly limited the role of local communities in forest fire management, as Ottawa was little interested in the knowledge and experience of northerners, including that of the Denesołine and Gwich'in. In 1979, after a particularly treacherous fire season, a federal review panel, fashioned after the Berger Inquiry process, was struck to assess the effects of the federal fire management policy. One of its key recommendations was for local communities to have greater involvement in the forest protection policy-making process (Ministerial Fire Review Panel 1980). The federal government did make some effort to gain local input, but the government's reputation as a colonial force in the region, combined with political unrest at the time associated with self-government negotiations, led to a less-than-successful consultation. Consequently, responsibility for forest protection devolved to the territorial government in 1987 . The forest protection policies of the territorial government were based on the events and realizations about forest fire activity from the 1970s, and specifically on those policies that recognized the "impossibility of complete protection under certain conditions and implied that fire management should allow for and incorporate the role of fire in the northern environment" (Janzen 1989, 123).

Today, the territorial government agency responsible for forest fire management in both the Denesọine and Gwich'in regions is Department of Environment and Natural Resources (formerly Renewable Resources), and forest fire operations are defined under the Forest Protection Act (GNWT 1998) and the Forest Fire Management Policy (GNWT 1997). In the Gwich'in region, a land claim settlement has created a formal role for the Gwich'in in the management of forests and other natural resources through institutions like the Gwich'in Tribal Council, the Gwich'in Renewable Resource Board, and local Renewable Resource Councils. Notwithstanding the fact that forest fire management was not part of the scope of the land claim negotiations, the Gwich'in do have the opportunity to exercise significant influence over the decisions of the territorial department. The Gwich'in Tribal Council, for example, works closely with ENR to ensure community views are included in fire management (GTC 2004). Similar opportunities also exist in the Denesơtine region to participate in forest fire management. Although there is no settled land claim in the region, the Forest Fire Management Policy (GNWT 1997) requirement to include local knowledge and consult about values at risk applies to peoples within settled land claims, as well as those in non-settled land claim areas. In Łutsël K'e, it is the local level Wildlife, Lands, and Environment Committee that deals with forest fire management issues. The Forest Fire 
Management Policy has a specific requirement to include local and Traditional Ecological Knowledge in forest fire management decision-making, which has become manifest in a variety of ways. The main opportunity however, is in the identification of values at risk defined as "human life and the specific or collective set of natural or cultural resources and improvements/developments that have measurable or intrinsic worth and that could or may be destroyed or otherwise altered by fire in any given area" (GNWT 1997, Sec. 4).

ENR holds community workshops at least once every five years to identify or review any changes in community-defined values at risk, evaluate the effectiveness of the forest fire management system, and to discuss any related issues of concern to community members. ENR officials yearly monitor the status of values at risk, such as cabin sites, via a spring helicopter survey; depending on the level of concern, one or two community members are also included in the spring survey. During the fire season, ongoing and informal communication between community members and ENR officials about the status and relative risks posed by fires in the region also provides opportunities for knowledge sharing between community members and the government.

TABLE 1: Opportunities for Including Traditional Knowledge in the Management of Forest Fires

\begin{tabular}{|c|c|c|c|}
\hline $\begin{array}{l}\text { Type of Local / Traditional } \\
\text { Knowledge }\end{array}$ & Mechanism & Institution / Process & Required by: \\
\hline \multirow[t]{3}{*}{$\begin{array}{l}\text { Cultural and ecological } \\
\text { values at risk }\end{array}$} & $\begin{array}{l}\text { GNWT Forest Fire } \\
\text { Management Policy }\end{array}$ & $\begin{array}{l}\text { ENR carries out consultation (workshops) in local } \\
\text { communities every five years }\end{array}$ & $\begin{array}{l}\text { Forest Fire Management } \\
\text { Policy } \\
\text { Section 2.(5)and 6.(3) }\end{array}$ \\
\hline & $\begin{array}{l}\text { Gwich'in Forest } \\
\text { Management Plan }\end{array}$ & $\begin{array}{l}\text { Research carried out by Gwich'in Renewable } \\
\text { Resource Board Staff } \\
\text { Gwich'in Renewable Resource Board, Gwich'in } \\
\text { Tribal Council and ENR carry out consultation with } \\
\text { communities including local Renewable Resource } \\
\text { Councils every five years }\end{array}$ & $\begin{array}{l}\text { Gwich'in Forest } \\
\text { Management Plan }\end{array}$ \\
\hline & Gwich'in Land Use Plan & $\circ \quad$ Five-year review of values and land use designations & $\begin{array}{l}\text { Gwich'in Comprehensive } \\
\text { Land Claim Agreement } \\
\text { / Gwich'in Land Use } \\
\text { Planning Board }\end{array}$ \\
\hline $\begin{array}{l}\text { Historical knowledge of } \\
\text { forest fire ecology }\end{array}$ & $\begin{array}{l}\text { GNWT Forest Fire } \\
\text { Management Policy }\end{array}$ & $\begin{array}{l}\text { ENR carries out consultation (workshops) in local } \\
\text { communities every five years }\end{array}$ & $\begin{array}{l}\text { Forest Fire Management } \\
\text { Policy } \\
\text { Section 2.(5) }\end{array}$ \\
\hline $\begin{array}{l}\text { Seasonal observations of } \\
\text { forest fire activity }\end{array}$ & $\begin{array}{l}\text { Opportunistic (e.g., } \\
\text { reporting of fire sitings) }\end{array}$ & $\begin{array}{ll} & \text { Direct contact with local ENR Renewable Resource } \\
\text { Officer } \\
\text { Telephone contact with regional ENR Fire Managers } \\
\text { in Inuvik and Fort Smith }\end{array}$ & Forest Protection Act 6.(1) b \\
\hline
\end{tabular}


FIGURE 2: Institutional Arrangements for Forest Fire Management in the Gwich'in and Denesọłine Regions

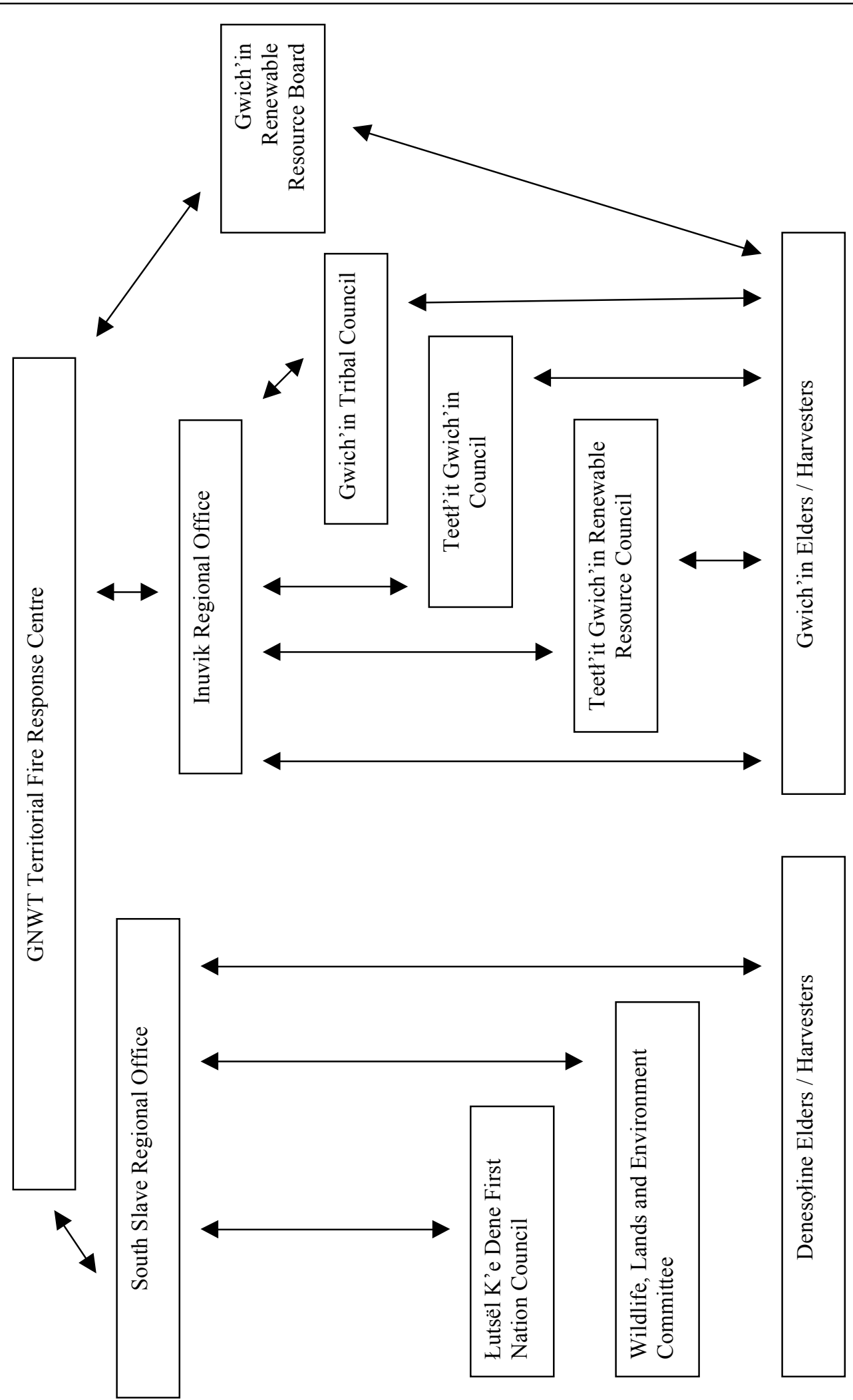




\section{Dealing with Non-Renewable Resource Development}

There are diverse institutions involved in the planning, assessment, management, and monitoring of non-renewable resource development in the Gwich'in and Denesọine regions. Traditional Knowledge is included in the decision-making processes of these institutions in a number of ways.

Landscape-level planning, including decisions about what lands and resources can or cannot be developed for mineral or oil and gas resources, takes place through a land use planning process that is the result of the Gwich'in Comprehensive Land Claim Agreement. The purpose of the land use plan, as defined in the agreement was to "protect and promote the current and future well-being of residents and communities in the Gwich'in area and have regard to all citizens of Canada" (Government of Canada 1992, Section 24.2.4a). During the land use planning process, significant local and Traditional Knowledge was gathered by Gwich'in organizations to identify heritage and conservation zones, special management zones, and general use zones (Gwich'in Land Use Planning Board 2004). This zoning system allows for multiple uses of land, water, and resources in certain areas, and controls activities, include resource development, in critical and sensitive environmental and heritage areas. It also aims to balance conservation values with those related to the use and development of the land, water, and resources (Gwich'in Land Use Planning Board 2004). It is important to note, however, that despite the identification of these zones, non-renewable resource development is still feasible in up to 90 percent of the Gwich'in Settlement Area (see Figure 1).

Currently, there is no land use planning process in place for the Denesołine region, and much of the traditional territory of the Denesołine is open for mineral resource development. Rights to minerals on Crown lands in the Northwest Territories are issued under the terms of the Canada Mining Regulations (Government of Canada 1979), and are granted to licensed prospectors through a free-entry claim staking process. The free entry system essentially gives exploration companies the right of entry and access on virtually all lands, the right to locate and register a claim without the intervention of the Crown, and the right to acquire a mineral lease. According to the free entry system, the only option open to government to limit or exclude mineral exploration is to withdraw lands from mineral entry for specific purposes. These would include lands proposed or defined as national parks; lands used as cemeteries or burial grounds; lands already under a mining claim, mining lease, or grant; and lands withdrawn under the Territorial Lands Act (Government of Canada 1985). As matters stand, there is no requirement under the free entry system to consult with Aboriginal peoples with an interest in the resources or lands being staked. Consequently, there are no required opportunities for communities to share Traditional Knowledge with government and or resource developers.

Management of oil and gas resources in the Northwest Territories falls under the Canada Petroleum Resources Act (Government of Canada 1985), which is administered by the Department of Aboriginal Affairs and Northern Development, and under the Canada Oil and Gas Operations Act (Government of Canada 1985), as administered by the National Energy Board. Unlike in the free entry system, rights to oil and gas resources are issued under a "rights issuance process," which includes a land parcel nomination and 
competitive bid process defined in the Canada Petroleum Resources Act. The Canada Oil and Gas Operations Act focuses on operations associated with oil and gas exploration, and development including production and conservation of resources, protection of the environment, and safety of workers. The Canada Oil and Gas Operations Act also requires that companies develop a benefits plan that sets out how northern businesses and residents will be consulted and benefit from the resource exploration and development activities (Government of Canada 1985).

The free entry system and rights issuance processes do not, however, exist in a vacuum; the federal government does have a fiduciary obligation to consult about activities that may affect Aboriginal rights as a result of Section 35 of the Constitution Act and Supreme Court rulings such as Delgamuukw Delgamukw v. British Columbia [1997], Haida Nation v. British Columbia (Minister of Forests)[2004], and Taku River Tlingit First Nation v. British Columbia [2004]. Consultation is also required in many parts of the Gwich'in Comprehensive Land Claim Agreement and requires "the provision of sufficient information to allow the Aboriginal party to prepare its views, the provision of sufficient time to allow an Aboriginal to prepare and present its views and full consideration of these views by the party required to consult" (Government of Canada 1992, 3). These requirements to consult create opportunities for the Denesọine and Gwich'in to include their Traditional Knowledge in decisions made about lands and resources proposed for development.

Resource rights are only one dimension of the non-renewable resource development picture. There are other opportunities for the Denesoline and Gwich'in to share their Traditional Knowledge through the land use permit, water license, and environmental assessment processes. The Mackenzie Valley Resource Management Act (Government of Canada 1998) requires that companies proposing to use lands and waters in the region apply for a land use permit and/or water license. Proponents apply for a land use permit and water license from Land and Water Boards of specific regions or in the case of applications that are in unsettled claim areas or defined as transboundary, the Mackenzie Valley Land and Water Board. These boards are responsible for carrying out preliminary screenings of land use permits and water license applications. Often the applications are approved under the Preliminary Screening process and the permit or licenses are issued directly. In some cases, however, where the screening has revealed significant public concern or significant adverse effects, the Board refers the application for an Environmental Assessment or Environment Impact Review.

The Mackenzie Valley Environmental Impact Review Board, a co-management body made up of individuals from across the Mackenzie region, is the central institution involved in the Environment Assessment and Environment Impact Review process. The Board defines Traditional Knowledge in terms of:

i. knowledge of the environment;

ii. knowledge about use and management of the environment; and

iii. values about the environment, must be considered, in all phases of the environmental assessment process (MVEIRB 2005, 5). 
TABLE 2: Planning, Managing, and Monitoring Non-Renewable Resource Development

\begin{tabular}{|c|c|c|c|}
\hline Process & Institution(s) & Mechanism & Required by: \\
\hline $\begin{array}{l}\text { Free Entry } \\
\text { System }\end{array}$ & NA & NA & $\begin{array}{l}\text { No requirement under the } \\
\text { Canadian Mining Regulations }\end{array}$ \\
\hline $\begin{array}{l}\text { Rights } \\
\text { Issuance } \\
\text { Process }\end{array}$ & $\begin{array}{l}\text { Department of } \\
\text { Aboriginal } \\
\text { Affairs and } \\
\text { Northern } \\
\text { Development }\end{array}$ & Consultation & $\begin{array}{l}\text { Required under terms and } \\
\text { conditions of the land claim } \\
\text { agreement Gwich'in } \\
\text { Comprehensive Land Claim } \\
\text { Agreement 12.4.13(b); 21.1.2; } \\
21.1 .3 \text {, } \\
\text { and in accordance with Supreme } \\
\text { Court rulings (e.g., Delgamukw } \\
\text { v. British Columbia [1997], } \\
\text { Haida Nation v. British } \\
\text { Columbia (Minister of Forests) } \\
\text { [2004], and Taku River Tlingit } \\
\text { First Nation v. British Columbia } \\
\text { [2004]) }\end{array}$ \\
\hline \multirow[t]{2}{*}{$\begin{array}{l}\text { Environmental } \\
\text { Assessment }\end{array}$} & $\begin{array}{l}\text { Gwich'in } \\
\text { Land and } \\
\text { Water Board; } \\
\text { Mackenzie } \\
\text { Valley Land } \\
\text { and Water } \\
\text { Board; } \\
\text { Mackenzie } \\
\text { Valley } \\
\text { Environmental } \\
\text { Impact } \\
\text { Review Board }\end{array}$ & $\begin{array}{l}\text { Boards consult with } \\
\text { communities to identify } \\
\text { issues that should be } \\
\text { considered in screening or } \\
\text { assessment; } \\
\text { communities potentially } \\
\text { affected by proposed activity } \\
\text { have an opportunity to review } \\
\text { applications and intervene in } \\
\text { proceedings }\end{array}$ & \multirow[t]{2}{*}{$\begin{array}{l}\text { Mackenzie Valley Resource } \\
\text { Management Act; } \\
\text { Mackenzie Valley Land and } \\
\text { Water Board Rules of Procedure } \\
\text { (1) } 34 \text { and (1) } 35 \text {; } \\
\text { Mackenzie Valley } \\
\text { Environmental Impact Review } \\
\text { Board Traditional Knowledge } \\
\text { Guidelines; } \\
\text { Discretion of the Board(s) }\end{array}$} \\
\hline & $\begin{array}{l}\text { Project } \\
\text { Proponent }\end{array}$ & $\begin{array}{l}\text { Consultation with } \\
\text { communities about } \\
\text { applications; } \\
\text { consultation/ Research for } \\
\text { Development Assessment } \\
\text { Report }\end{array}$ & \\
\hline $\begin{array}{l}\text { Protected } \\
\text { Areas Strategy }\end{array}$ & $\begin{array}{l}\text { Protected } \\
\text { Areas Strategy } \\
\text { Steering } \\
\text { Committee }\end{array}$ & $\begin{array}{l}\text { Communities carry out } \\
\text { Traditional Knowledge } \\
\text { research and other studies as } \\
\text { part of their preparation of a } \\
\text { Protected Area Proposal }\end{array}$ & Protected Areas Strategy 3.2.1(a) \\
\hline
\end{tabular}




\begin{tabular}{|c|c|c|c|}
\hline Process & Institution(s) & Mechanism & Required by: \\
\hline $\begin{array}{l}\text { Gwich'in } \\
\text { Land Use } \\
\text { Planning } \\
\text { Process }\end{array}$ & $\begin{array}{l}\text { Gwich'in } \\
\text { Land Use } \\
\text { Planning } \\
\text { Board }\end{array}$ & $\begin{array}{l}\text { Board carries out consultation } \\
\text { with communities every five } \\
\text { years as part of their } 5 \text { year } \\
\text { review of the Gwich'in Land } \\
\text { Use Plan }\end{array}$ & $\begin{array}{l}\text { Gwich'in Comprehensive Land } \\
\text { Claim Agreement } \\
\text { Gwich'in Land Use Plan Section } \\
6.6\end{array}$ \\
\hline \multirow[t]{3}{*}{$\begin{array}{l}\text { Cumulative } \\
\text { Effects } \\
\text { Research and } \\
\text { Monitoring in } \\
\text { the Mackenzie } \\
\text { Valley region }\end{array}$} & $\begin{array}{l}\text { Cumulative } \\
\text { Effects } \\
\text { Assessment } \\
\text { and } \\
\text { Management } \\
\text { Framework }\end{array}$ & $\begin{array}{l}\text { Traditional Knowledge has } \\
\text { been documented through } \\
\text { community involvement } \\
\text { projects }\end{array}$ & $\begin{array}{l}\text { Cumulative Effects Assessment } \\
\text { and Management Framework is } \\
\text { the result of commitments made } \\
\text { by the Federal Government } \\
\text { during the Environmental } \\
\text { Assessment of the Diavik } \\
\text { Diamond Mine. }\end{array}$ \\
\hline & $\begin{array}{l}\text { Cumulative } \\
\text { Impact } \\
\text { Monitoring } \\
\text { Program }\end{array}$ & $\begin{array}{l}\text { Traditional Knowledge has } \\
\text { been documented through } \\
\text { community monitoring and } \\
\text { capacity building projects }\end{array}$ & $\begin{array}{l}\text { Mackenzie Valley Resource } \\
\text { Management Act }\end{array}$ \\
\hline & $\begin{array}{l}\text { Non- } \\
\text { Governmental } \\
\text { Organizations } \\
\text { and other } \\
\text { Agencies } \\
\text { (e.g., West } \\
\text { Kitikmeot } \\
\text { Slave Study } \\
\text { Society) }\end{array}$ & $\begin{array}{l}\text { Traditional Knowledge has } \\
\text { been documented about } \\
\text { valued ecosystem elements } \\
\text { and processes such as caribou } \\
\text { movements }\end{array}$ & $\begin{array}{l}\text { Various } \\
\text { (e.g., West Kitikmeot Slave } \\
\text { Study Society Terms of } \\
\text { Reference) }\end{array}$ \\
\hline \multirow[t]{3}{*}{$\begin{array}{l}\text { Project } \\
\text { Specific } \\
\text { Monitoring }\end{array}$} & $\begin{array}{l}\text { Independent } \\
\text { Environmental } \\
\text { Monitoring } \\
\text { Agency }\end{array}$ & $\begin{array}{l}\text { Communities share local and } \\
\text { Traditional Knowledge with } \\
\text { Board members on an } \\
\text { opportunistic basis and } \\
\text { during annual meetings in } \\
\text { communities }\end{array}$ & $\begin{array}{l}\text { Environmental Agreement } \\
\text { between the Federal and } \\
\text { Territorial Governments and } \\
\text { BHP Billiton Inc. Condition of } \\
\text { Approval under the CEAA } \\
\text { Environmental Assessment }\end{array}$ \\
\hline & $\begin{array}{l}\text { Environmental } \\
\text { Monitoring } \\
\text { Advisory } \\
\text { Board }\end{array}$ & $\begin{array}{l}\text { Communities share local and } \\
\text { Traditional Knowledge with } \\
\text { the Board through their } \\
\text { community representative, } \\
\text { during annual meetings and } \\
\text { through specific projects }\end{array}$ & $\begin{array}{l}\text { Environmental Agreement } \\
\text { between the Federal and } \\
\text { Territorial Governments, } \\
\text { Aboriginal Groups and Diavik } \\
\text { Diamond Mines Inc. Condition } \\
\text { of the Approval under the CEAA } \\
\text { Comprehensive Study. }\end{array}$ \\
\hline & $\begin{array}{l}\text { Snap Lake } \\
\text { Monitoring } \\
\text { Agency }\end{array}$ & $\begin{array}{l}\text { Communities share local and } \\
\text { Traditional Knowledge with } \\
\text { the Board through their } \\
\text { community representative, } \\
\text { during annual meetings and } \\
\text { through specific projects. }\end{array}$ & $\begin{array}{l}\text { Environmental Agreement } \\
\text { between the Federal and } \\
\text { Territorial Governments, } \\
\text { Aboriginal Groups and DeBeers } \\
\text { Canada Ltd. Condition of } \\
\text { Approval under the Mackenzie } \\
\text { Valley Environmental Impact } \\
\text { Review Board } \\
\text { Environmental Assessment. }\end{array}$ \\
\hline
\end{tabular}


FIGURE 3: Arrangements Associated with the Planning, Assessment, Management, and Monitoring of Non-renewable Resource Development

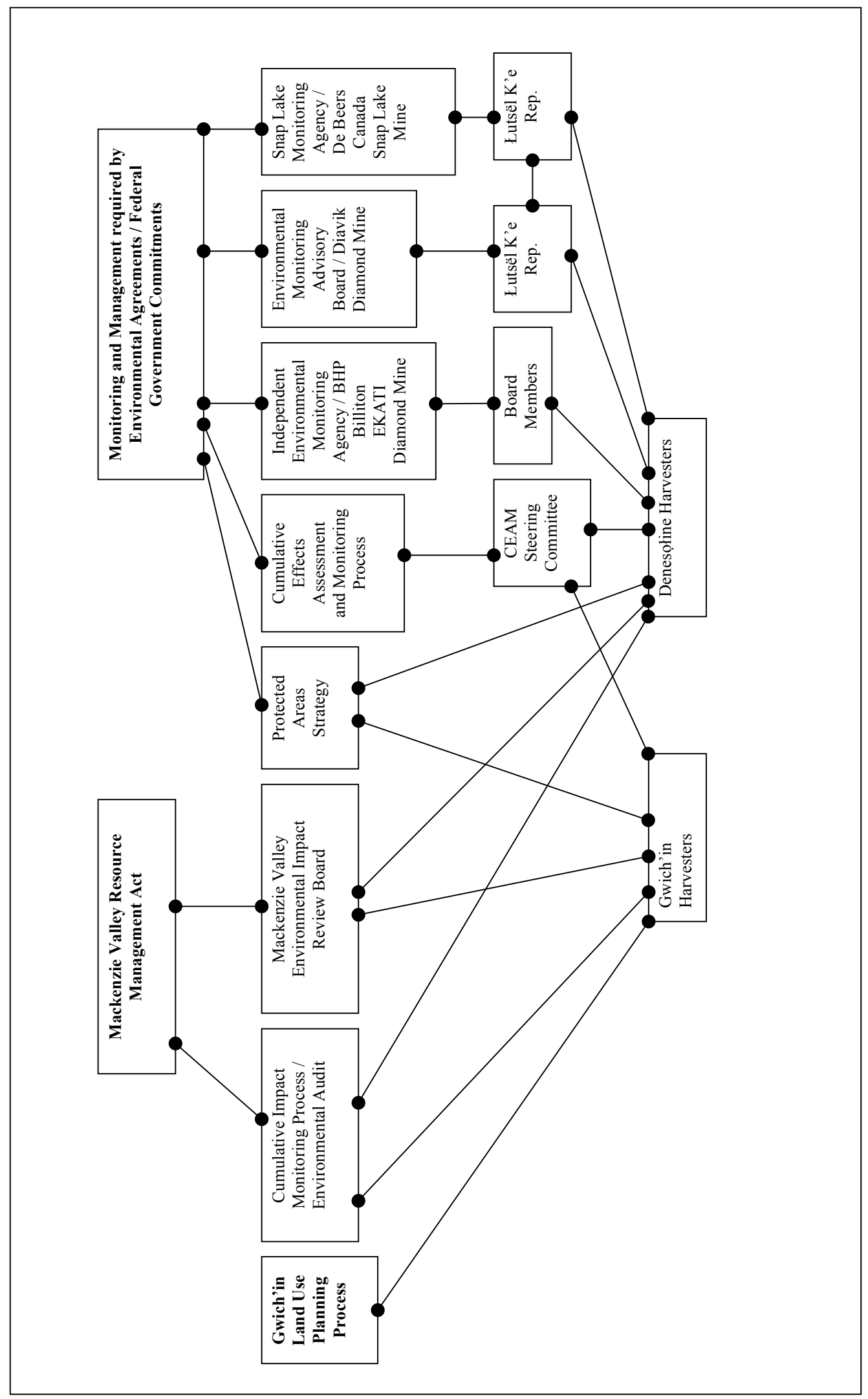


There are a variety of opportunities for including Traditional Knowledge in these processes. Project proponents are encouraged to consult with Aboriginal communities potentially affected by a project prior to making an application, although methods of consultation and the extent of effort placed on gathering local and Traditional Knowledge can vary significantly, depending on the proponent and the stage of project development. During the Preliminary Screening process, the land and water boards also seek input directly from local communities about the application and potential effects of proposed project activities.

The Mackenzie Valley Environmental Impact Review Board generally requires more indepth consideration of local and Traditional Knowledge during environmental assessments. Proponents of larger projects, such as a mine or pipeline, are usually required to work with local communities to document relevant local and Traditional Knowledge and demonstrate how that knowledge has been used or will be used in the future to mitigate, monitor, and/or manage adverse environmental effects. The Board itself also solicits local and Traditional Knowledge to identify issues and develop terms of reference for assessment, and in the review of the environmental assessment report, through formal technical hearings and/or community hearings. While there are many challenges associated with the use of Traditional Knowledge in the screening and assessment process, the Board perceives Traditional Knowledge as having a valuable role in increasing understanding of the environment in which a development is proposed, the potential effects of that development, and the significance of those effects (MVEIRB 2005, 7).

To date, the Board has undertaken hundreds of preliminary screenings and over thirty environmental assessments. In the case of full environmental assessments, all applications were approved by the Board, with the exception of the New Shosoni Ventures application to carry out diamond exploration at Drybones Bay (MVEIRB 2004). In that case, an approved water license would have allowed New Shosoni Ventures to carry out advanced diamond exploration activities at Drybones Bay, located within the traditional lands of the Denesołine, Yellowknives Dene, and North Slave Metis Alliance. During the environmental assessment, the Mackenzie Valley Environmental Impact Review Board heard arguments from the Yellowknives Dene, Łutsël K'e, and others about the cultural value of the lands and resources proposed for development.

[W] e don't want our cultural identity treated like points on a map that can be simply managed and mitigated or made less important. Those places, the cultural representations, the landscape and the information those places contain are not just archaeological sites. They're part of our social, spiritual and cultural identity. ... Those places out there are how we communicate who we are and ... pass on our culture to our children (Beaulieu 2003).

In its final deliberations, the Board determined that New Shosoni Ventures had not made adequate efforts to understand the cultural value of the land and resources they proposed to develop. Drawing on the Traditional Knowledge shared by elders and leaders, including Chief Darrell Beaulieau, the Board rejected New Shosoni's application, stating that "the project was likely to cause an impact on the environment so significant that it could not be mitigated" (MVEIRB 2004, vi). 
A variety of other opportunities for including Traditional Knowledge have been created in relation to planning, monitoring, and management of mining activities in the Denesọine region. Companies such as the BHP Billiton, Rio Tinto Diamonds, and DeBeers Canada have, from time to time, funded Traditional Knowledge studies to assist them in identifying ways to mitigate or manage the effects of their projects. BHP Billiton and other members of the Chamber of Mines have also funded Traditional Knowledge studies through a regional funding agency (West Kitikmeot Slave Study Society 1998). In the Gwich'in region, oil and gas companies have started to take similar steps. The extent of Traditional Knowledge documented to date, however, has been limited.

There are also several ad hoc monitoring agencies in the Denesoline region. The Independent Environmental Monitoring Agency, the Environmental Monitoring Advisory Board, and the Snap Lake Monitoring Agency aim to include local and Traditional Knowledge in the monitoring of specific diamond mining projects, specifically the BHP Billiton EKATI Mine, Rio Tinto Diamonds' Diavik Diamond Mine, and DeBeers Canada's Snap Lake Diamond Mine. It is anticipated that similar agencies will be developed for monitoring the construction and operations of the proposed Mackenzie gas pipeline and its ecological effects. In addition to these project specific opportunities, local and Traditional Knowledge are also considered in cumulative effects monitoring and management through the Cumulative Impact Monitoring Program and the Cumulative Effects Assessment and Management Framework, which to date has been done largely through community research projects. Clearly there are many opportunities for including Traditional Knowledge in the planning, assessment, management, and monitoring of non-renewable resource development in the Gwich'in and Denesoline regions. The environmental assessment and regulatory process offer a number of avenues, however: institutions created under the Mackenzie Valley Resource Management Act, the Gwich'in Comprehensive Land Claim Agreement, and ad hoc agreements have also been important.

\section{Coping with the Threat and Effects of Climate Change}

Traditional Knowledge can also make useful contributions to our understanding of the integrated social and ecological effects of climate change (Nuttall et al. 2004). While the bulk of climate change research has been based on Western science, there is growing recognition of Traditional Knowledge as a result of research with Sach's Harbour and other Arctic communities (Nichols et al. 2004; Reidlinger and Berkes 2001; Krupnik and Jolly 2002).

Community organizations, such as the Teetł'it Gwich'in Renewable Resource Council and Łutsël K'e Wildlife Lands and Environment, share their knowledge about climate change and its effects from time to time during regular council and committee meetings. Discussion is often precipitated by an event such as a late caribou migration, a late freezeup, or some major human impact. In other cases, information presented to the councils or committee by representatives from regional organizations such as the Dene Nation or Gwich'in Tribal Council, a government department, or some other agency addressing the climate change issue, leads to the sharing of knowledge by these local organizations and their constituents. 
There are also a variety of regional institutions that have created opportunities for sharing Traditional Knowledge on climate change. In the Gwich'in region, one key agency is the Arctic Borderlands Knowledge Co-op (Kofinas et al. 2002). The main activities of the Co-op include interviewing local harvesters, and communicating results through annual workshops and over the Internet. The Gwich'in Renewable Resources Board and the community of Fort McPherson are among the original participants of the Co-op and, by 2004, the Co-op had expanded to include more than ten communities from the Yukon, Gwich'in Settlement Area, and Inuvialuit Settlement Region of the Northwest Territories. Other organizations involved in studying or addressing the effects of climate change in the Gwich'in and Denesołine regions include the Environmental Monitoring and Assessment Network North, Climate Change and Adaptation Research Network, and Northern Climate ExChange. The Northern Climate ExChange in particular has a mandate to "support the contributions of indigenous peoples to the climate change knowledge base by promoting the acceptance of Traditional Knowledge and aboriginal expertise" (NCE 2004). These agencies are, however, centred in Whitehorse, and are largely funded and coordinated through the Yukon College. The extent to which they are able to draw on the Traditional Knowledge of northern peoples in the Gwich'in and Denesọine regions depends upon the capacity of other regional and community-level organizations in the NWT, including the Aurora College and Aurora Research Institute in Inuvik.

Most federal government policies and strategies on climate change have focused on southern populations and on strategies for limiting greenhouse gas emissions. To date there has been little recognition of the effects of climate change on northern communities. The Government of the Northwest Territories, too, has done little to recognize or deal with the effects of climate change. While the territorial government has stated that it is committed to the Kyoto Accord, no targets to limit greenhouse gas emissions for the Northwest Territories have been set.

The best-known institutions related to climate change are those created by the United Nations Framework Convention on Climate Change. These institutions have resulted in international recognition of the climate change issue and specific targets for limiting greenhouse gas emissions despite the Canadian Federal Government's failure to support further climate change action. These agreements made use of existing institutions like the Intergovernmental Panel on Climate Change and created new bodies, such as the Conference of the Parties, which is the main body involved in the implementation of the United Nations Framework Convention on Climate Change. These institutions rely overwhelmingly on Western science in their decision-making and there are few opportunities for including Traditional Knowledge.

An exception here is the work of the Arctic Council and their Arctic Climate Impact Assessment completed in 2004. The Arctic Council may be among the most effective institutions at linking the traditional knowledge of northern communities to decisionmakers at international levels. As described on its website, "the Arctic Council [i] $s$ a high level intergovernmental forum to provide a means for promoting cooperation, coordination and interaction among the Arctic States, with the involvement of the Arctic Indigenous communities and other Arctic inhabitants on common Arctic issues" (Arctic Council n.d.). This organization is made up of eight state members-Canada, Denmark, 
Finland, Iceland, Norway, the Russian Federation, Sweden, and the United States and has a number of permanent members, including the Gwich'in Council International and the Arctic Athabaskan Council (see Figure 4). Nations represented on the Arctic Council, including Canada, are able to bring forward knowledge to international circles through their representation at the Conference of the Parties. The Report of the Arctic Climate Impact Assessment highlights the current and potential effects of climate change on Arctic ecosystems and peoples (Hassol 2004). Although the Arctic has been largely overlooked in previous international discussions on climate change, this report has the potential to reorient the debate to include the perspectives of northerners including Traditional Knowledge.

FIGURE 4: The Institutional Arrangements Associated with Climate Change

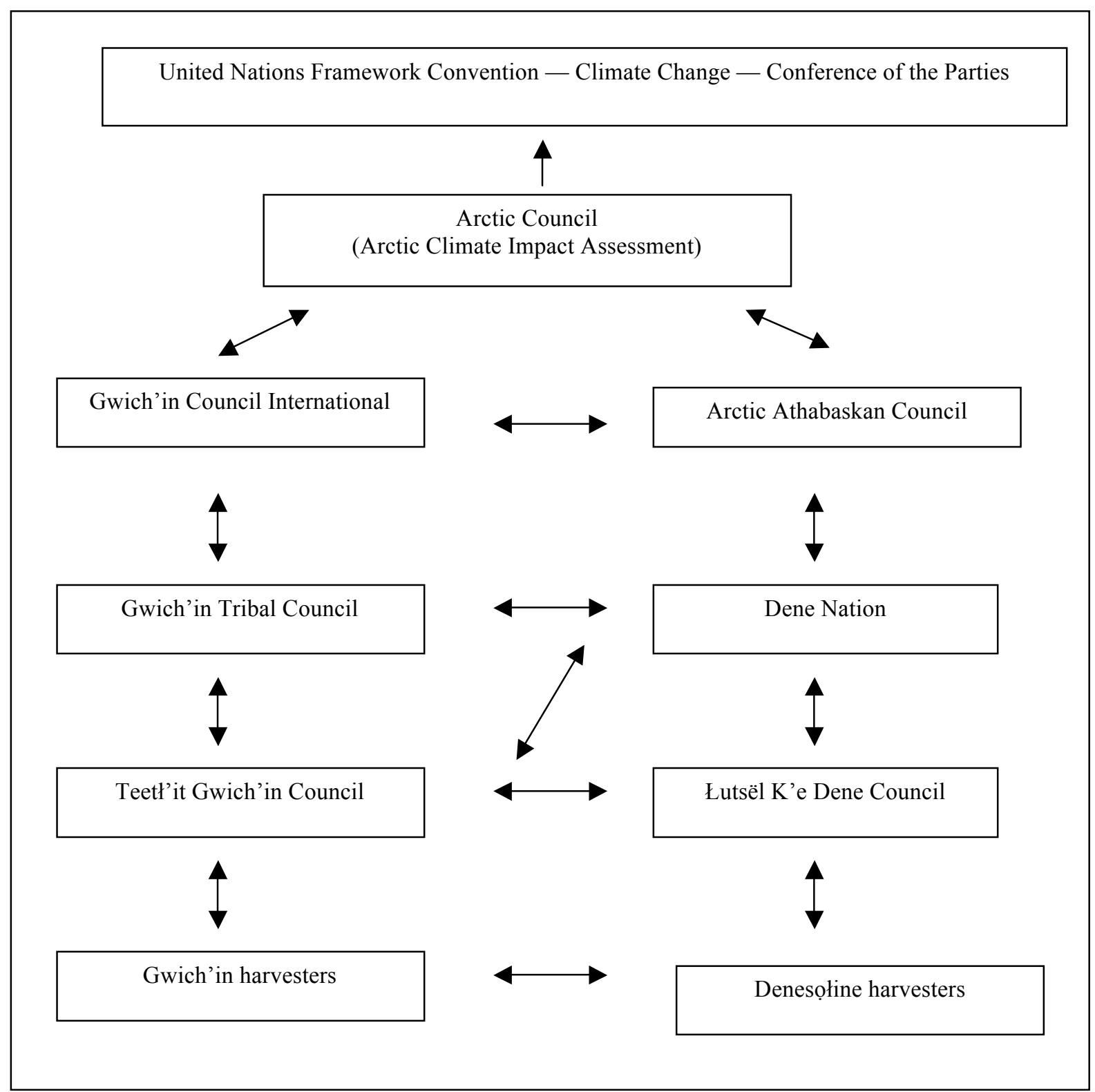




\section{Discussion}

This paper has focussed on the patterns of opportunities for people of the NWT to participate in linking Traditional Knowledge to resource management decision-making and how these opportunities differ by ecological scale. By exploring the issues of forest fire, nonrenewable resource development, and climate change, I have identified the opportunities that exist in both settled and unsettled land claim regions. In this next section, I will classify these opportunities according to seven different kinds of institutional arrangements.

Arguably, the most powerful or legally binding opportunities are tied to legal requirements for consultation. Even where there is no legislation requiring governments to consult, as is the case with forest fire management and institutions involved in addressing climate change, there are opportunities. Policies, guidelines, protocols, and other similar mechanisms effectively serve as "soft-law," and result in increased awareness and recognition of the value of Traditional Knowledge and the role of Aboriginal peoples.

TABLE 3: Summary of Institutional Arrangements

\begin{tabular}{|l|l|}
\hline \multicolumn{2}{|c|}{ Summary of Institutional Arrangements } \\
\hline 1 & Regional resource management legislation (e.g., Mackenzie Valley Resource Management Act) \\
\hline 2 & Land claim agreements (e.g., Gwich'in Comprehensive Land Claim Agreement) \\
\hline 3 & Obligations created by Supreme Court decisions on Aboriginal rights (e.g., requirements to consult) \\
\hline 4 & $\begin{array}{l}\text { Ad hoc agreements / contracts between Aboriginal groups, governments and industry (e.g., } \\
\text { Environmental Agreement for the Diavik Diamond Mine) }\end{array}$ \\
\hline 5 & Obligations created by policies, protocols, guidelines (e.g., Fire Suppression Policy) \\
\hline 6 & Formal and informal international arrangements (e.g., Kyoto Protocol / Arctic Council) \\
\hline 7 & Informal knowledge sharing arrangements (e.g., Arctic Borderlands Knowledge Co-op) \\
\hline
\end{tabular}

Ad hoc agreements, such as those created for the management and monitoring of diamond mines in the Denesọine region, create other key opportunities. Unlike some other arrangements rigidly defined in legislation or policy, these negotiated arrangements allow for innovation and creativity. For example, the Environmental Agreements for the Diavik Diamond Mine and DeBeers Snap Lake Diamond Mine have created unique mechanisms for including Traditional Knowledge in site-specific monitoring and cumulative effects monitoring, as well as in industry and government decision-making about mine management and mitigations.

Co-management arrangements involving Aboriginal groups and governments have created many opportunities. Formal co-management agreements developed as a result of land claim agreements, such as the Gwich'in Comprehensive Land Claim Agreement, create an obligation to include Traditional Knowledge in many decision-making processes. The Mackenzie Valley Environmental Impact Review Board and the Mackenzie Valley Land and Water Board are examples of co-management institutions in which representatives of the Aboriginal communities work together with government to make decisions about non-renewable resource development activities. The discussion on forest fire management describes a process of shared decision-making that is similar to many formal comanagement arrangements. Arguably, the culture of co-management in many regions of 
the North has had a spill-over effect in other resource management areas. Even though no formal co-management arrangement is in place, for example, the Government of the Northwest Territories works with the Gwich'in and Denesołine to make decisions about many aspects of forest fire management. The absence of a settled land claim or formal comanagement arrangement is a continued concern for some communities in the Denesọine region, however. While they value the opportunities to share knowledge and participate in resource management decision-making, they fear that their traditional territory is being badly managed by institutions in which they have no formal role.

Multi-stakeholder processes facilitate sharing of Traditional Knowledge among communities, regional organizations, and governments at many different scales. The Arctic Borderlands Knowledge Co-op is a useful example of the horizontal linkages that exist between communities across the Gwich'in, Inuvialuit, and Yukon areas, and how a regional perspective on climate change can be built based on local observations and experiences. The Arctic Council is another example of a multi-stakeholder body that draws together northern organizations and nations, and linkages created by the Council are both horizontal and vertical. The Council facilitates horizontal dialogue and interaction between representatives of its member nations and organizations, such as the Gwich'in Council International, through annual meetings and ongoing project activities. There are multiple vertical linkages associated with the work of the Arctic Council as well. The Council provides a forum in which Arctic nations can discuss issues of common concern and develop research strategies, such as the Arctic Climate Impact Assessment, to address those concerns. Each of the member nations, as well as Indigenous organizations, also engage with their constituents creating further vertical interaction. For example, the Inuit Circumpolar Conference engages with its members in Canada through elected leaders of the four land-claims settlement regions-Inuvialuit, Labrador, Nunavik, and Nunavut-who also, in turn, communicate with beneficiaries from each of these regions. These vertical interactions facilitate and are facilitated by the horizontal interactions of smaller scale institutions, such as those shown in Figure 4. The Gwich'in Tribal Council for example, regularly communicates with the Dene Nation about issues in the Northwest Territories, such as contaminants. In recent years, climate change has also been a key issue of discussion.

Although these organizations appear to have had little impact on policies related to climate change to date, the kind of long-term knowledge collection that has taken place through the Co-op, and the detailed research undertaken by the Arctic Council, may have some influence over future policy. This kind of influence is not without precedent. An investigation into the institutions involved in dealing with persistent organic pollutants suggests that knowledge sharing between communities, regions, and circumpolar nations can raise critical awareness and action at national and international levels (Berkes et al. 2005).

Multi-stakeholder agencies like the Diavik Diamond Mine Environmental Monitoring Advisory Board highlight how Traditional Knowledge can influence the planning, management, and monitoring of non-renewable resource development. Environmental Agreements such as that developed for the Diavik Diamond Mine create a legal obligation for government and industry to consider and respond to recommendations made by 
Aboriginal groups. These Environmental Agreements and the legal obligations defined within them seem to provide communities such as Łutsël K'e with powerful tools to influence the management of their lands and resources.

Some institutions offer very limited opportunities for using Traditional Knowledge. The Canada Mining Regulations, enabled under the Territorial Lands Act (Government of Canada 1985), for example, are based on an approach to resource access that does not allow for input from local Aboriginal communities. In effect "miners can enter onto the traditional lands of Aboriginal peoples, stake claims, go to lease, and produce and export minerals, all without the consent of the Aboriginal peoples concerned and without compensation to those peoples" (Bankes and Sharvit 1999, 1). This system however, has been criticized as unconstitutional and contrary to Supreme Court decisions such as Delgamukw v. British Columbia [1997], Haida Nation v. British Columbia (Minister of Forests) [2004], and Taku River Tlingit First Nation v. British Columbia [2004] (Bankes and Sharvit 1999). It is likely that governments, as well as industry, will face increased obligations to consult with Aboriginal communities, whose lands and resources may be affected by mineral development in the future.

\section{Looking Forward}

The challenge of incorporating Traditional Knowledge in resource management decision-making about fire, resource development, and climate change is fraught with barriers that range from technical and capacity issues associated with the documentation of appropriate Traditional Knowledge and participation of Aboriginal peoples, to more deeply rooted problems of social relations, trust, and power. There are also obvious economic barriers, a problem that has not been much discussed in the literature to date.

The premise behind the use of Traditional Knowledge, according to both the academic literature and policies such as the Government of the Northwest Territories Traditional Knowledge Policy, is that it can lead to significant improvements in resource management practice. In many incidences, however, the incorporation of Traditional Knowledge is not simply a benign or win-win scenario for all involved. It has real cost, particularly when "listening to the elders" would lead to resource conservation rather than resource development. It is these costs associated with conservation which may be the greatest concern to government, industry, and related decision-makers.

Such costs can be understood through the use of a trade-off curve. In most resource development scenarios, one can imagine that the territorial and federal governments, as well as many Aboriginal peoples, are in a conflicted position of being supportive of and obligated to consider Traditional Knowledge on the one hand ( $\mathrm{x}$ axis) but also open proponents of such projects as the proposed Mackenzie Gas Project (y axis). Those in positions of power, such as members of the Mackenzie Valley Environmental Impact Review Board, consequently are faced with the challenge of finding a balance between the guidance of the elders (and by extension land and resource conservation) and benefits of resource development deemed to be important by others. As point (a) in the tradeoff curve (Figure 5) suggests, it may be possible to incorporate some Traditional Knowledge to a certain point with limited opportunity cost. However, for resource management decisions 
to be completely guided by Traditional Knowledge would, at least in some instances, result in significant opportunity cost or the forgoing of many kinds of resource developments and their benefits (b). As the Northwest Territories prepares for even greater levels of resource development in the coming years, more research on the socio-economic implications of "meaningful consideration" of Traditional Knowledge is needed.

FIGURE 5: Trade-Offs between Resource Development and the Inclusion of Traditional Knowledge

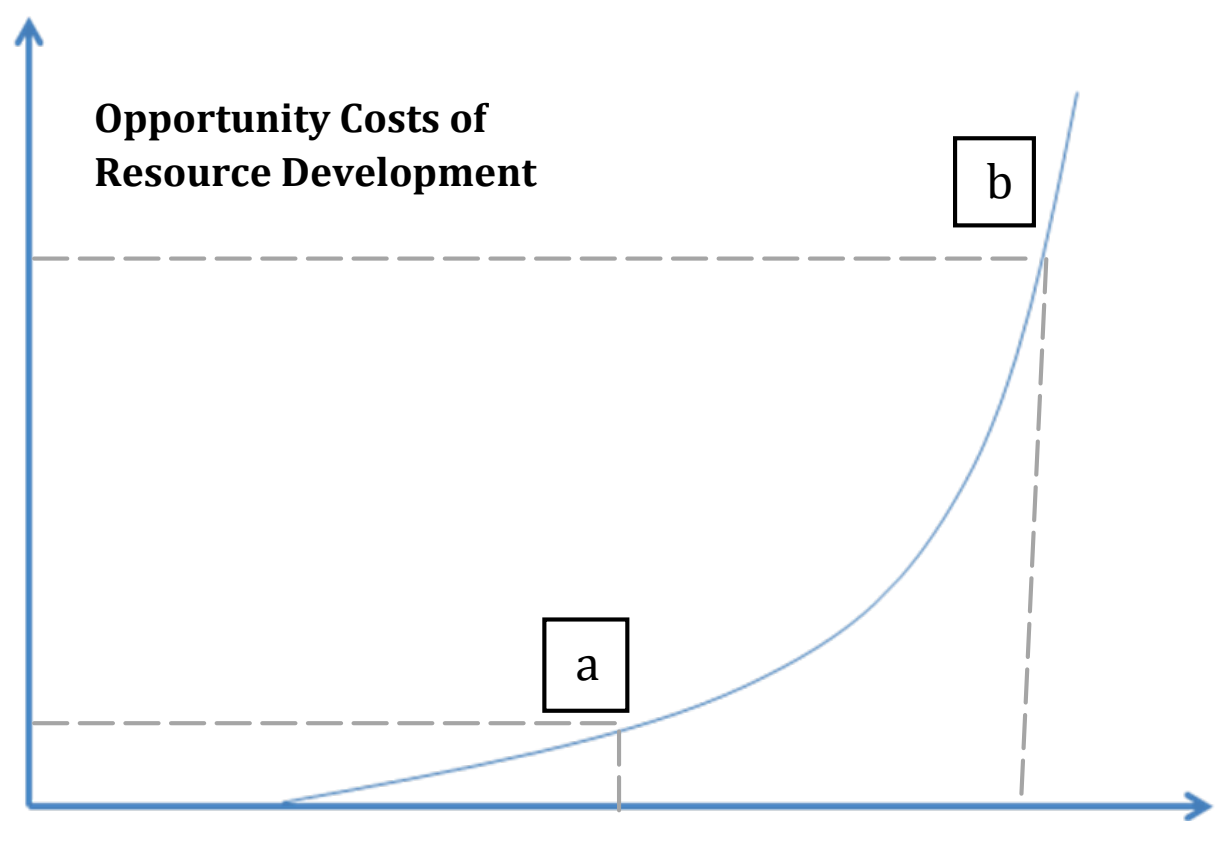

\section{Incorporation of Traditional Knowledge}

\section{Conclusions}

Scale has become an emerging area of interest and research with respect to Traditional Knowledge, particularly in northern regions (Gagnon and Berteaux 2009; Berkes 2002; Duerden and Kuhn 1998). Equally relevant to our understanding of how Traditional Knowledge manifests at different scales are the ways in which opportunities for incorporating Traditional Knowledge in decision-making vary by scale. Land claim settlements have played a particularly important role in creating these new opportunities. However, even where land claims have not been settled, the culture of co-management that has been created by agreements in other regions of the north and Supreme Court rulings such as Delgamukw, Haida, and Taku River Tlingit, have led to new kinds of relationships between government and Aboriginal peoples. 
Many of these new relationships can be characterized as multi-scale governance arrangements (Berkes et al. 2005; Berkes 2002). This paper builds on previous research on multi-scale governance by suggesting how local, regional, territorial, national, and international institutions can function together. These kinds of multi-scale governance arrangements are not unique to the Gwich'in: other Aboriginal groups across the north are observing and experiencing similar kinds of changes in their regions and are working with institutions beyond the local level (Natcher et al. 2004; Nichols et al. 2004; Krupnik and Jolly 2002; INTFMA 1996).

There are still many questions about the potential use of Traditional Knowledge in resource management, and there is, arguably, a long way to go before Traditional Knowledge and Western science are considered to be on equal ground in decision-making processes in the Northwest Territories and elsewhere. However, the opportunities highlighted in this paper are useful starting points for Aboriginal peoples, governments, and other institutions seeking to learn and work together to address resource management issues of common concern.

\section{Notes}

1. A study was conducted in 1999-2000 of an oil drilling site developed and closed in the late 1960s near Caribou River (66 30.98’ N, 134' 04.26’W), which is defined as R4-FS (CLSR 78826) of the Gwich'in Comprehensive Land Claim Agreement. It was determined that $1,100 \mathrm{~m} 3$ of soil at the site is impacted with DDTs at levels above the CCME criterion, with the majority of the material in the river bank, in an area susceptible to erosion by the Peel River (Gwich'in Land and Water Board 2000).

2. The "little yellow bird" is likely a warbler, possibly a Wilson's Warbler. Research north east of the community in the Thelon River area suggests that the range of this species has expanded in a northeasterly direction (Norment 1999). Given that this is a species of bird that is new to the area, it is understandable that the elder would not have a Chipewyan name. 


\section{Bibliography}

Agrawal, A. 2002. "Indigenous knowledge and politics of classification." International Social Science Journal 173: 287-97. http://dx.doi.org/10.1111/1468-2451.00382.

Akaitcho Territory Dene First Nations. 2001. "Akaitcho Interim Measures Agreement." Ottawa: Akaitcho Territory Dene First Nations and Her Majesty the Queen in Right of Canada and the Government of the Northwest Territories. December 20, 2004.

Arctic Council Secretariat. (n.d.). Arctic Council. "About Arctic Council.” No date. Accessed January 2012 via http://arcticportal.org/arctic-council

Bankes, N., and C. Sharvit. 1999. "Free-Entry Mineral Regimes and Aboriginal Title." Northern Perspectives 25 (3): 13.

Battiste, M., and J. Henderson. 2000. Protecting Indigenous Knowledge and Heritage: A Global Challenge. Saskatoon: Purich.

Beaulieu, Chief D. 2003. Yellowknives Dene First Nation. November 26, 2003, Mackenzie Valley Environmental Impact Review Board. Transcript PR \#255.

Bergeron, Y., P. J. H. Richard, C. Carcaillet, S. Gauthier, M. Flannigan, and Y. T. Prairie. 1998. "Variability in Fire Frequency and Forest Composition in Canada's Southeastern Boreal Forest: A Challenge for Sustainable Forest Management." Conservation Ecology 2 (2): 6.

Berkes, F. 2002. "Cross-Scale Institutional Linkages for Commons Management: Perspectives From the Bottom Up." In The Drama of the Commons, ed. E. Ostrom, T. Dietz, N. Dolšsak, P. C. Stern, S. Stonich and E. U. Weber, 293-321. Washington DC: National Academy Press.

- - - 2008. Sacred Ecology: Traditional Ecological Knowledge and Resource Management. Philadelphia: Taylor and Francis.

Berkes, F., N. Bankes, M. Marschke, D. Armitage, and D. Clark. 2005. "Cross-Scale Institutions and Building Resilience in the Canadian North." In Breaking Ice: Renewable Resource and Ocean Management in the Canadian North, ed. F. Berkes, R. Huebert, H. Fast, M. Manseau, and A. Diduck, 225-48. Calgary: University of Calgary Press.

Berkes, F., J. Colding, and C. Folke, eds. 2003. Navigating Social-Ecological Systems: Building Resilience for Complexity and Change. Cambridge: Cambridge University Press.

Berkes, F. and D. Jolly. 2001. "Adapting to climate change: social-ecological resilience in a Canadian western Arctic community." Conservation Ecology 5 (2): 18.

Christensen, J. and M. Grant. 2006. "How Political Change Paved the Way for Indigenous Knowledge: The Mackenzie Valley Resource Management Act.” Arctic 60 (2): 115-23. 
Cruikshank, J. 2004. “Uses and Abuses of 'Traditional Knowledge': Perspectives from the Yukon Territory." In Cultivating Arctic Landscapes: Knowing and Managing Animals in the Circumpolar North, ed. D. G. Anderson and M. Nuttall, 17-32. New York: Berghahn.

Delgamukw. v. British Columbia [1997].

Duerden, F., and R. G. Kuhn. 1998. "Scale, Context, and Application of Traditional Knowledge of the Canadian North." Polar Record 34 (188): 31-38. http://dx.doi. org/10.1017/S0032247400014959.

Ellis, S. E. 2005. "Meaningful Consideration? A Review of Traditional Knowledge in Environmental Decision Making." Arctic 58 (1): 66-77.

Flannigan, M.D., Y. Bergeron, O. Engelmark, and B.M. Wotton. 1998. "Future Wildfire in Circumboreal Forests in Relation to Global Warming." Journal of Vegetation Science 9: 469-76. http://dx.doi.org/10.2307/3237261.

Folke, C., L. Pritchard Jr., F. Berkes, J. Colding, and U. Svedin. 2007. “The Problem of Fit Between Ecosystems and Institutions: Ten Years Later." Ecology and Society 12 (1): 30.

Freeman, M. and L.N. Carbyn, eds. 1988. Traditional Knowledge and Renewable Resources Management in Northern Regions. Occasional Paper No. 20. Edmonton: Boreal Institute for Northern Studies.

Gagnon, C. A., and D. Berteaux. 2009. "Integrating Traditional Ecological Knowledge and Ecological Science: A Question of Scale." Ecology and Society 14 (2): 19.

Gwich'in Land Use Planning Board. 2004. Implementing the Gwich'in Land Use Plan: A Five Year Workplan (2003-2008). Inuvik: Gwich'in Land Use Planning Board.

Government of Canada. 1985a. Canada Petroleum Resources Act. R.S., 1985, c. 36.

_-_. 1985b. Canada Mining Regulations / Northwest Territories and Nunavut Mining Regulations. C.R.C., c. 1516.

- - - 1985c. Territorial Lands Act (R.S.C., 1985, c. T-7)

-_- 1985d. Canadian Oil and Gas Operations Act ( R.S.C., 1985, c. O-7).

-_- 1992. Gwich'in Comprehensive Land Claim Agreement. Comprehensive Land Claim Agreement between Her Majesty the Queen in Right of Canada and the Gwich'in as Represented by the Qwich'in Tribal Council. Ottawa: Indian and Northern Affairs Canada.

_-_.1993a. Nunavut Land Claims Agreement. Agreement between the Inuit of the Nunavut Settlement Area and Her Majesty the Queen in Right of Canada. Ottawa, ON: Indian and Northern Affairs Canada.

-_- .1993b. Sahtu Dene and Metis Comprehensive Land Claim Agreement. Ottawa, ON: Indian and Northern Affairs Canada. 
___. 1998. Mackenzie Valley Resource Management Act. ( S.C. 1998, c. 25).

Government of the Northwest Territories. 1988. Forest Protection Act. R.S.N.W.T. (1988a). Revised Statutes of the Northwest Territories, Scientist Act. Yellowknife, NWT.: Territorial Printer.

-_- 1997a. Traditional Knowledge Policy 53.03. Revised March 10, 2005.

_-_. 1997b. Forest Fire Management Policy 52.07. Revised February 5, 2005.

Gwich'in Land and Water Board. 2000. Caribou / Peel River Environmental Project-Draft

Proposal. Prepared for Shell Canada Ltd and Indian and Northern Affairs-Canada Waste Management Program. Inuvik: Gwich'in Development Corporation. Accessed January 2005. http://www.mvlwb.ca/glwb/Registry/G01B001\%20 Application.pdf

Gwich'in Tribal Council. 2004. Forest Management. Inuvik: Gwich'in Tribal Council. Accessed November 25, 2011. www.gwich'in.nt.ca

Haida Nation v. British Columbia (Minister of Forests) [2004].

Hassol, S. 2004. Impacts of a Warming Arctic: Arctic Climate Impact Assessment. Fairbanks, AK: International Arctic Research Center, University of Alaska Fairbanks.

Howard, A., and F. Widdowsen. 1996. "Traditional Knowledge threatens environmental assessment.” Policy Options 17: 34-36.

Howitt, R. 2001. Rethinking Resource Management: Justice, Sustainability and Indigenous Peoples. London and New York: Routledge.

INTFMA (Innu Nation Task Force on Mining Activities). 1996. Ntesinan nteshiniminan nteniunan-Between a Rock and a Hard Place. Sheshatshiu, Labrador: Innu Nation Office.

Janzen, S. S. 1989. The Burning North: A History of Fire and Fire Protection in the Northwest Territories. MA diss., Univ. of Alberta.

Kendrick, A., 2003. "Caribou Co-management in Northern Canada: Fostering Multiple Ways of Knowing." In Navigating Social-ecological Systems, ed. F. Berkes, J. Colding, C. Folke, 241-71. Cambridge: Cambridge University Press.

Kofinas, G., with the communities of Aklavik, Arctic Village, Old Crow and Fort McPherson. 2002. "Community Contributions to Ecological Monitoring: Knowledge Co-op-Production in the US-Canada Arctic Borderlands." In The Earth is Faster Now: Indigenous Observations of Arctic Environmental Change, ed. I. Krupnik and D. Jolly, 54-91. Fairbanks, AK: Arctic Research Consortium of the United States and Arctic Studies Center, Smithsonian Institution.

Kokelj, S. and GeoNorth Ltd. 2002. Drilling Mud Sumps in the Mackenzie Delta Region: Construction, Abandonment and Past Performance. Yellowknife, NWT: Department of Indian and Northern Affairs.

Krupnik, I. and D. Jolly. 2002. The Earth is Faster Now: Indigenous Observations of Arctic Environmental Change. Fairbanks, AK: Arctic Research Consortium of the United States and Arctic Studies Center, Smithsonian Institution. 
Landhäusser, S. M. and R. W. Wein. 1993. "Post-Fire Vegetation Recovery and Tree Establishment at the Arctic Treeline: Climate Change-Vegetation Response Hypotheses." Journal of Ecology 81: 665-72.

Lynch, A. H., W. L. Chapman, J. E. Walsh, and G. Weller. 1995. "Development of a Regional Climate Model of the Western Arctic." Journal of Climate 8: 1555-70. http://dx.doi.org/10.1175/1520-0442(1995)008<1555:DOARCM>2.0.CO;2.

McCrank, N. 2008. Road to Improvement-The Review of the Regulatory Systems Across the North. Report to the Honourable Chuck Strahl, Minister of Indian Affairs and Northern Development. Ottawa: Government of Canada.

Mackenzie Valley Environmental Impact Review Board (MVEIRB). 2004. Report of Environmental Assessment and Reasons for Decision on New Shoshoni Ventures environmental assessment. Yellowknife, NWT: Mackenzie Valley Environmental Impact Review Board.

-_- 2005. Guidelines for Incorporating Traditional Knowledge in Environmental Impact Assessment. Yellowknife, NWT: Mackenzie Valley Environmental Impact Review Board.

Ministerial Fire Review Panel. 1980. Report of the Ministerial Fire Review Panel (1979-80). Ottawa: Ministry of Supply and Services.

Nadasdy, P. 2003. Hunters and Bureaucrats: Power, Knowledge and Aboriginal State Relations in the Southwest Yukon. Vancouver: UBC Press.

Natcher, D. C., C. Hickey and S. Davis, 2004. “The Political Ecology of Yukon Forestry: Managing the Forest as if People Mattered.” International Journal of Sustainable Development and World Ecology 11: 343-55. http://dx.doi. org/10.1080/13504500409469838.

Nichols, T., F. Berkes, D. Jolly, and N. Snow. 2004. "Climate Change and Sea Ice: Local Observations from the Canadian Western Arctic." Arctic 57 (1): 68-80.

Norment, C.J., A. Hall, and P. Hendricks. 1999. "Important Bird and Mammal Records in the Thelon River Valley, Northwest Territories: Range Expansions and Possible Causes." The Canadian Field Naturalist 113 (3): 375-85.

Northern Climate ExChange (NCE). 2004. About Us. Whitehorse, YK: NCE. Accessed June 1, 2011. http://www.taiga.net/nce/about.html.

National Round Table on Environment and Economy (NRTEE). 2001. Aboriginal Communities and Non-Renewable Resource Development. Ottawa: National Round Table on Environment and Economy.

Nuttall, M., F. Berkes, G. Wenzel, B. Forbes, T. Vlassova, and G. Kofinas. 2004. "Chapter 11 - Hunting, Herding, Fishing and Gathering: Indigenous Peoples and Renewable Resource Use in the Arctic." In Impacts of a Warming Arctic: Arctic Climate Impact Assessment (ACIA) Scientific Report, ed. S. J. Hassol. Fairbanks, AK: International Arctic Research Center, University of Fairbanks. 
Parlee, B., F. Berkes, and Teetł'it Gwich'in Renewable Resource Council. 2006. "Gwich'in Knowledge of Ecological Variability: Implications for Commons Management." Human Ecology 34: 515-28.

Reidlinger, D., and F. Berkes. 2001. "Contributions of Traditional Knowledge to Understanding Climate Change in the Canadian Arctic." Polar Record 37: 315-28.

Seccombe-Hett, P., and J. Walker-Larsen. 2004. Forest growth after fire and clearing for seismic lines in the upland habitats of the Gwich'in Settlement Area (GRRB Report \#04-05). Inuvik: Gwich'in Renewable Resources Board.

Stevenson, M. G. 2006. “The Possibilities of Difference: Rethinking Co-Management.” Society for Applied Anthropology 65 (2): 167-80.

Stewart-Harawira, M. 2005. The New Imperial Order: Indigenous Responses to Globalization. London: Zed.

Taku River Tlingit First Nation v. British Columbia [2004].

Usher, P. J. 2000. “Traditional Knowledge in Environmental Assessment.” Arctic 53 (2): 183-93.

Weber, M.G. and M.D. Flannigan. 1997. "Canadian Boreal Forest Ecosystem Structure and Function in a Changing Climate: Impacts on Fire Regimes." Environmental Review 5: 145-66. http://dx.doi.org/10.1139/er-5-3-4-145.

Wenzel, G. 1999. “Traditional Ecological Knowledge and Inuit: Reflections on TEK Research and Ethics." Arctic 52 (2): 113-24.

West Kitikmeot Slave Study Society (WKSS). 1998. Final Study Report. Yellowknife: Government of the Northwest Territories.

White, G. 2006. "Cultures in Collision: Traditional Knowledge and Euro-Canadian Governance Processes in Northern Land-Claim Boards." Arctic 59 (4): 401-14. 


\section{Appendix}

Arctic Borderlands Knowledge Coop

ABKC
ACIA
CEAMF
CIMP
COGOA
CPRA
EC
ENR
GNWT
GLUP
GCLCA
GLWB
GRRB
GTC
GSCI
MVRMA
MVLWB
MVIERB
NWT
UNCCC
WKSS

Arctic Climate Impact Assessment

Cumulative Effects Assessment \& Management Framework

Cumulative Impact Monitoring Program

Canadian Oil and Gas Operations Act

Canadian Petroleum Resources Act

Environment Canada

Environment and Natural Resources

Government of the Northwest Territories

Gwich'in Land Use Plan

Gwich'in Comprehensive Land Claim Agreement

Gwich'in Land and Water Board

Gwich'in Renewable Resources Board

Gwich'in Tribal Council

Gwich'in Social and Cultural Institute

Mackenzie Valley Resource Management Act

Mackenzie Valley Land and Water Board

Mackenzie Valley Environmental Impact Review Board

Northwest Territories

United Nations Convention on Climate Change

West Kitikmeot Slave Study Society 